\title{
Second Time Lucky? A Tale of Two Systems
}

\section{Hans Lehmann \\ Victoria University of Wellington, Wellington, New Zealand}

\author{
Hans.Lehmann@vuw.ac.nz
}

\begin{abstract}
This paper reports on the continuation of a research that was started in 1994, when an attempt to implement a global information system in a large multi-national firm was investigated over the next 6 years. Already by 1999, however, it became clear that this, first, implementation was a resounding failure - but as a longitudinal, large scale case study it contributed richly to a wider study of the nature and specific character of such international information systems. In the last months of 2003 the firm, in a new structure, under new management, re-started the quest for global information systems support for its - now considerably more complex - international operations. The development, acquisition and implementation of the resulting suite of systems took the best part of 6 years again - but turned out to be an apparently successful project. This research, started in 2010, has two objectives: firstly to establish a comprehensive case history of the second project; and then to compare both cases to analyze differences and analogies in their respective approaches, contextual influences and structural underpinnings to validate and extend the previously established grounded theory.
\end{abstract}

Keywords: Global Information Systems Implementation, Issues in International Information Systems, cultural and technical issues in global IS, Grounded Theory Method

\section{Introduction}

The implementation of any large information system is still a very risky undertaking (British Computer Society, 2004) and none more so than when it comes to support the operations of large multi-national enterprises. This research is about a global enterprise that made two attempts at creating an international information system (IIS) in succession. It is fortunate that the same researchers, the author(s) can investigate both attempts. The firm, a large co-operative enterprise in the land-based sector (further on referred to as the CO-OP since the firm wishes to stay anonymous.), made its first attempt in the mid-nineties but did not achieve a single one of its objectives. After a period of consolidation and organizational re-grouping they then attempted it again some years later and, judging from the research so far, this time their IIS deployment enjoyed a fair amount of acceptance.

The research project in hand will initially establish a comprehensive case history of how the sec-

Material published as part of this publication, either on-line or in print, is copyrighted by the Informing Science Institute. Permission to make digital or paper copy of part or all of these works for personal or classroom use is granted without fee provided that the copies are not made or distributed for profit or commercial advantage AND that copies 1) bear this notice in full and 2) give the full citation on the first page. It is permissible to abstract these works so long as credit is given. To copy in all other cases or to republish or to post on a server or to redistribute to lists requires specific permission and payment of a fee. Contact Publisher@InformingScience.org to request redistribution permission. ond IIS was conceived, acquired, and implemented. In the main analysis both case studies will be compared and, taking a longitudinal view over both projects, the 'Grounded Theory of IIS' established in the first case study will then be enhanced and extended. This paper is structured as follows: in the next section the research problem and question will be discussed, followed by a short 
description of the research method. Section four provides a summary of the first case study and section five outlines the current case history. This is followed by a first analysis of the findings and some preliminary conceptualizations of the dynamics found in the case. The paper concludes with a listing of next steps in the project.

\section{Research Problem and Research Question}

The application of information technology in support of global operations seems to be of scant interest to information systems (IS) researchers and looks like it has been roundly ignored by international business academics. In the practitioner community the consensus is that IIS are in the first instance a major and potentially disastrous stumbling block for global operators - as born out by a considerable body of anecdotal evidence in the literature. Most of this 'evidence' is contained as cases in anthologies and monographs on large information systems failure, i.e., Flowers (1996), Yourdon (1997), Glass (1998) and Collins and Kirsch (1999).

This dichotomy of practitioners' serious difficulties and sparse applied research by academia motivated the author(s) to set out on a large Grounded Theory research project with multi-national companies (MNCs) in 1995. Its aim was to establish a set of theoretical foundations for IIS, focusing firstly on what makes IIS a specific generic type of IS and, secondly, on identifying the specific factors that engender user acceptance of IIS. The first case study in the project was that of the CO-OP, a rich story of a nascent IIS that, alas, remained stillborn. In the grounded theory tradition of theoretical sampling this was then followed by a successful IIS, but in a smaller MNC. To saturate the findings theoretically, another case of a successful IIS was investigated, this time with an international operator comparable in size with the CO-OP. A substantive grounded theory of IIS was then formulated at the conclusion of the project in 2001. Various accounts of the first case and of the full theory were published (Lehmann, 1996, 1997, 1998, 2000, 2003, 2004, 2005, 2010; Lehmann \& Gallupe 2005).

In 2008 the opportunity arose to carry out another a case study with the CO-OP. Starting around 2001 they had initiated, now for the second time, a programme, i.e., a series of projects, with the object to introduce information systems that could support their extensive and complex global operations. By 2005 they concluded preliminary and pilot projects and commenced the roll-out of an SAP platform around the world. In mid-2008 the complete functionality was handed over by the implementation team to the last of its users, concluding the world-wide installation of the first IIS constellation.

This rare opportunity of investigating the same object of research, i.e., an MNC embarking on implementing an IIS with largely the same set of objectives, twice, in different settings and with different outcomes adds another level of depth to the analysis. The first phase is a comparative case study that allows the distillation of factors for success of the second project with a sharper lens then in the study before: it is a comparison of two activities with identical objectives in largely the same business context and external environment. Secondly, however, a longitudinal element is added to this research by adding into the analysis the developments in the internal structure of the firm, in the approaches to the problem, and in the self-image and vision of the enterprise - and, of course, in the nature of the information technology available. These are a new set of variables and factors to the interpretation of the second case. Their presence will undoubtedly have a significant influence on the factor dynamics and actor constellations of the enhanced theory. In grounded theory terminology this will extend the substantive range of the theory and deepen understanding of the relationships in the dynamics that underlie and drive the user acceptance of IIS.

The research questions for the first project were, firstly, to find out what (if any) characteristics make IIS a specific, generic class of IS and, secondly, to establish the factors that make an IIS 
acceptable to its users. The CO-OP case contributed significantly towards discharging the first question. It also contributed a clear constellation of factors and processes that led to the ultimate demise of their IIS project - but only the other cases from different organizations shed light on the nature of the factors that engender success with embedding (and exploiting) IIS in MNCs.

For the current project the first research question is a natural extension of the previous study:

\section{[Q1] What is the nature and interaction of the specific factors that shape user accep-} tance of an IIS?

Being able to investigate the longitudinal changes in the business and information technology make-up of the very enterprise that executed both projects allows the extension of the research to examine how they effect the factor dynamics in Q1 - especially those that contributed to the improved acceptance of the second project:

\section{[Q2] How did the changes that occurred within the CO-OP between projects influence the factors that specifically contribute to the increased user acceptance of SAP?}

\section{IIS Definition and Literature Overview}

The term 'International Information Systems' was coined by Buss (1982) and proved to be a better fit than the notion of 'common systems' created by Keen, Bronsema, and Auboff in the same year. To differentiate IIS from other types of distributed or 'inter-organizational' systems they have been defined (Lehmann, 1996) as:

Distributed information systems that are implemented at various sites within one enterprise to support similar business activities in highly diverse environments, commonly found across country boundaries.

It is this high degree of diversity across a number of critical dimensions - culture, business practices, technical context, and social mores - that can make IIS orders of magnitude more complex. This complexity first hinders their creation and deployment and then, even more so, their research. Lessons from information systems that are distributed across less diverse environments are often insufficient and inapplicable for IIS.

In-depth coverage of the literature on IS in an international setting is available in more detail elsewhere: Hamelink (1984) covers the early research; Sethi and Olson (1993) give a comprehensive overview until then; Gallupe and Tan (1999) bring it more up-to-date and Lehmann \& Gallupe (2005) update it further still. Critically, they found that over the two decades of research nearly $40 \%$ of the papers in their analysis deal with instances and issues of local information systems, but their authors interpret 'international' as any country other than the one the authors are resident in.

Most reviews tend to agree that past research into IIS is sparse, sporadic and diffuse. If anything, this scarcity of interest and research has intensified: a ProQuest search conducted 5/1/2010 on http://proquest.umi.com.helicon.vuw.ac.nz/pqdweb of 'information systems' in the keyword and abstracts of articles in scholarly journals since 2000 found 19,014 papers. Adding the conjunction 'multinational enterprises' reduces the search result to just five papers over the same period. The majority of academic research is furthermore largely confined to theoretical treatments of the subject, with very little evidence of applied research, even in the practitioner literature.

The first research project showed, however, that literature in a wide variety of business and IS research was relevant to embed the resultant theorems into the current state-of-the-art. It is expected that the discussion of the final results of the current research will require the same amount of inclusion of cross-disciplinary findings and a comprehensive literature analysis will be carried out then. 


\section{Research Method}

The method deemed most conducive to answering the research questions in this research is the Grounded Theory method (Glaser, 1978; Glaser \& Strauss, 1967). Grounded Theory exists in two variations: one following the approach and philosophy outlined by Glaser and Strauss (1967) and later upheld by Glaser $(1978,1995,1998)$. Strauss (1987) developed a variation for use by his students. Strauss and Corbin $(1990,1994)$ then further procedurised the method for smaller, human-relations oriented research. This was, however, roundly condemned and refuted by Glaser (1992). This research project uses the 'classic' (Glaser \& Strauss, 1967) method. Grounded Theory was selected because:

- First, Grounded Theory is a "theory discovery methodology" (Martin \& Turner, 1986, p. 141) and therefore the method of choice when there is no overarching theory for the research in hand (Denzin \& Lincoln, 1994; also, albeit indirectly, Feyerabend, 1988);

- Second, Grounded Theory, by definition, incorporates the complexities of the context into an understanding of the phenomenon (Martin \& Turner, 1986; Orlikowski, 1993; Pettigrew, 1990). This capability of dealing with the often complex structural, organisational and information technology issues encountered by multinational enterprises is of particular importance here.

Furthermore, an IIS is an 'ecology' (Davenport, 1997, Davenport \& Prusak, 1997) of information technology and organisational elements. The research method most suited for the study therefore does not align itself conveniently behind one dominant research paradigm. Instead, a mix of (post)positivist, interpretivist and, to a smaller extent, critical approaches is required for dealing with the organisational, managerial and technological aspects respectively.

Guba and Lincoln (1994) provide a framework for the analysis of the paradigm positions against its constituent elements with respect to the practical issues encountered. Using this as a framework, Table 1 below shows the positions taken with respect to selected issues and paradigm elements with relevance for this study.

This capability of accommodating multiple paradigms in one method is especially relevant in this research case because the second research question explicitly asks how the longitudinal business developments and organisational, i.e., structural and developmental, changes have affected the outcome of the IIS project. Grounded Theory, as a "general" and "paradigmatically neutral" methodology (Glaser, 1998) is therefore particularly appropriate here.

However, Grounded Theory was originally designed for conceptualising the processes underlying human-to-human relationships. This is too narrow a context for investigating how multinational firms use information technology. Already in the original case study, the classic Grounded Theory method had to be extended (following the spirit of Glaser and Strauss, 1970) to deal with case studies effectively. This was achieved with the introduction of a two-tier coding structure.

First, individual interviews, observations and other data were treated as single "texts"1. Appropriately grouped together they then became the elements of another, larger text, the case (hi)story itself. The data was first coded into primary categories (such as people, places, events, and other concrete phenomena) and then conceptualised into theoretical categories (such as causal/correlational linkages, hypothesised motivational and/or management processes). Coding as well as theoretical sampling for new data occurred at both levels of "text", single and composite. The enquiry case thus followed an analysis protocol (in Yin's, 1989, terms) of multiple cases with

\footnotetext{
${ }^{1}$ In the interpretivist sense this is defined as a "collection of symbols expressing layers of meaning" (Miles \& Huberman, 1994, p. 8)
} 
analyses both within each case (first) and (later on) between cases, where the unit of analysis was multi-level "text". This method (shown in Table 1 below) is now again being used in this research undertaking.

\begin{tabular}{|c|c|c|c|c|}
\hline \multirow[b]{2}{*}{$\begin{array}{l}\text { Paradigm } \\
\text { Elements }\end{array}$} & \multicolumn{4}{|c|}{ Spectrum of Paradigm Positions } \\
\hline & $\begin{array}{l}\text { Traditional } \\
\text { Positivism }\end{array}$ & Post-Positivism & Constructivism & Critical Theory \\
\hline $\begin{array}{l}\text { "Voice"' } \\
\text { Epistemology }\end{array}$ & $\begin{array}{l}\text { A dispas- } \\
\text { sionate ob- } \\
\text { server... }\end{array}$ & & & \\
\hline $\begin{array}{l}\text { Inquiry aim } \\
\text { Epistemology }\end{array}$ & \multicolumn{2}{|c|}{$\begin{array}{l}\text {...explaining the 'interaction' be- } \\
\text { tween the 'factors' that shape 'us- } \\
\text { er acceptance' and... }\end{array}$} & $\begin{array}{l}\text {...how they are in- } \\
\text { fluenced by } \\
\text { 'changes' in the or- } \\
\text { ganisation... }\end{array}$ & \\
\hline $\begin{array}{l}\text { Nature of } \\
\text { Knowledge } \\
\text { Ontology }\end{array}$ & & $\begin{array}{l}\text {...expressed in } \\
\text { theorems, which } \\
\text { are... }\end{array}$ & $\begin{array}{l}\text {... 'mimetic' con- } \\
\text { structions, that may } \\
\text { include... }\end{array}$ & $\begin{array}{l}\text {...structural/political } \\
\text { and historical insights } \\
\text { from which... }\end{array}$ \\
\hline $\begin{array}{l}\text { Accumula- } \\
\text { tion of } \\
\text { Knowledge } \\
\text { Methodology }\end{array}$ & & $\begin{array}{l}\text {... cause-effect } \\
\text { relations are pos- } \\
\text { tulated... }\end{array}$ & $\begin{array}{l}\text {...which are gener- } \\
\text { alised by the simi- } \\
\text { larity of incidents. }\end{array}$ & \\
\hline
\end{tabular}

After a long preliminary phase of obtaining permission and access and negotiating confidentiality levels, fieldwork on the case study started in late 2009. Up to the end of April 2010 the data gathering has involved 14 hours of (six) fact-finding interviews in four locations and the study of some 400 pages of documentary data (reports, memos, minutes, etc). In this phase the objective is first and foremost to establish a comprehensively validated case history. In future phases evaluations from business and technical perspectives will be solicited internationally and follow-up interviews and documentary data gathering will be carried out throughout the CO-OP's regional and local offices. The Grounded Theory method applies theoretical sampling from incident to incident until the nascent theory has reached theoretical saturation, i.e., when new data does not add or change the conceptual constructs established so far. For this reason it is not possible to provide a priori estimates of sample characteristics. However, it is intended to conclude the data gathering by the end of 2010 - intricacies of travel itineraries and logistics permitting.

\section{Prologue: The First Case Study}

The CO-OP is a land-based, co-operative exporter of agricultural producers. In the 1970s it lost its largest export market and, in a dramatic scramble, had to establish local presences in other markets to survive. By changing from strong central control to giving maximum authority to hastily established local 'bridge-heads' it not only survived, but prospered enormously. By the turn

\footnotetext{
${ }^{2}$ This is the position of the inquirer vis-à-vis the research subjects, especially with respect to the impact any research findings may have on them
} 
of the millennium its revenue was well in excess of USD (\$)10bn and it is now the largest exporter of its products and the seventh-largest enterprise in its industry worldwide.

In 1992 a new CEO had taken over and realized that the degree of autonomy that had served them so well in the 'frontier years' now needed to transform itself into a 'think global-act local' enterprise so that it could compete in its markets with the other global firms - the likes of Nestle, Kraft and Cargill. The CIO, alas, misunderstood this move as a return to the very central control of old and initiated a project to install a globally standard IT platform in all the CO-OP's offices worldwide. The project met with strong user resistance from the outset - for two reasons: one was the professional ineptitude of the IT people, a product of the overall IT-illiteracy in the CO-OP's then executive, which manifested itself in proposing an inadequate, unworkable systems solution. The second was the resulting absence of any buy-in from the regions - who saw the whole project not only as practically useless, but also as an underhand attempt to wrest control over 'their' business from them.

The project, initiated in 1995, continued through a number of ever more acrimonious political battles until 1999 when, following a damning consultants' report, it was abandoned. With the exception of some financial software, none of its technology artefacts were implemented.

In the first study (as a case history, Lehmann, 2004; as a key part the grounded theory, Lehmann, 2005; in full detail as part of a monograph, Lehmann, 2010) this cycle of infighting and rejection went through five iterations before it was terminated. The relationships between the factors involved in these dialectic dynamics are represented as "cause-effect-loops" ${ }^{3}$ introduced by Weick (1979, pp. 65-88). Such “causal networks" have been introduced by Lewin's $(1938,1952)$ force-field notions in psychology and sociology (e.g., Maruyama's 'morphogenesis', 1968 or Bateson's 'regenerative loops', 1972) but have gained popularity also in business and economics disciplines ${ }^{4}$. They are considered particularly useful because they "respect [the] complexity" of cyclical interactions where causation is not unilateral and where cause and effect can be interchangeable (Miles \& Huberman, 1994, p. 153). Figure 1 shows the "rejection cycle" part of the full response cycle found in the first study.

The project, because it was started in isolation by IT (connector 1) was deficient functional quality (2) from the outset, which lead to the initial rejection (3) by business. This increased the isolation by the IT people, with a negative effect on functional quality, but it increased the tendency to engage in adversarial politics (4) to force acceptance. However, this made the business people increase their rejection, and so this "deviation- amplifying" cycle (Weick, 1979, p. 72) continued in a downward spiral until the project was terminated.

The new project, however, seems to have avoided this fate altogether and right from the outset. What was different?

\footnotetext{
${ }^{3}$ The technique is directional (rather than solely correlational). A change in the same direction, i.e. "the more of A, the more of B" or "the less of A, the less of B" is labelled with a "plus' (+) sign. A minus (-) sign signals a change into the opposite direction, i.e. "the more of A, the less of B" or the "less of A, the more of B".

4 Early examples are: Lindsley, Brass, and Thomas (1995) in strategic management, investigating links between efficacy and performance; Herrscher and Herrscher (1990) in economics, studying hyperinflation; and Montazemi and Chan (1990) assessing the predictive quality of expert systems.
} 


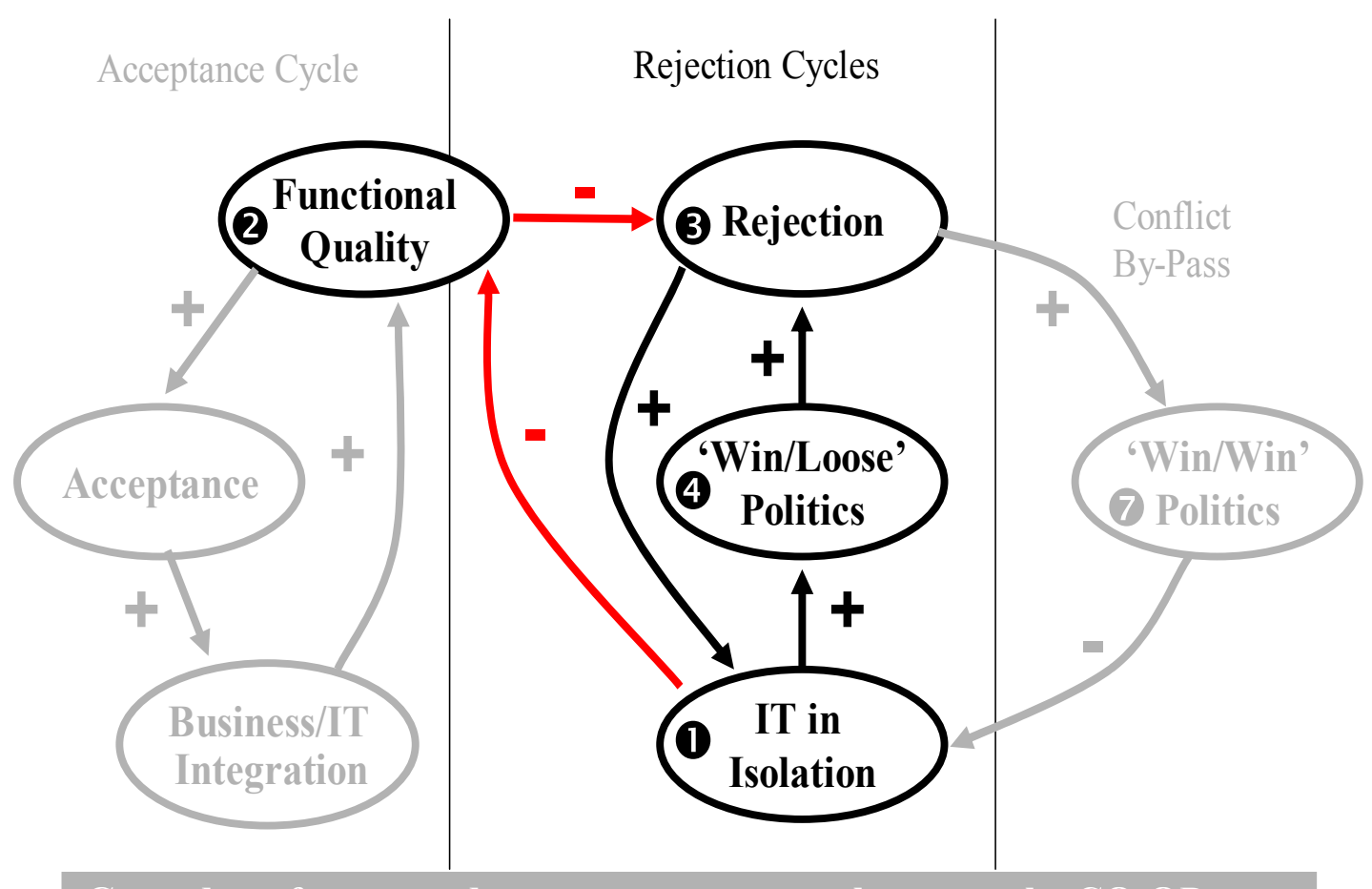

Greyed out factors and connectors are not relevant to the $\mathrm{CO}-\mathrm{OP}$ case

Figure 1. The cycle of rejection found in the CO-OP case (after A+, 2005)

\section{Second Time Lucky? \\ The Study of the Second IIS Project (so far...)}

The study was instigated at the CO-OP's executive level and this is where interviews and other data gathering have started. By the end of April 2010 a detailed chronology of the case history has emerged and is outlined in Table 2 below.

Table 2. Annotated Chronology of the CO-OP's Second IIS Project

\begin{tabular}{|c|c|c|c|}
\hline Time & Business Developments & IT developments & Comments \\
\hline 2001 & $\begin{array}{l}\text { Regions have re-asserted } \\
\text { their autonomy after the } \\
\text { global IIS project was } \\
\text { terminated }\end{array}$ & $\begin{array}{l}\text { Minimal in the centre; } \\
\text { independent develop- } \\
\text { ments in the regions }\end{array}$ & $\begin{array}{l}\text { CO-OP now uses ORACLE Financials in } \\
\text { some regions; }\end{array}$ \\
\hline $\begin{array}{l}\text { Late } \\
2002\end{array}$ & $\begin{array}{l}\text { CO-OP becomes and } \\
\text { incorporated enterprise } \\
\text { with a shareholder struc- } \\
\text { ture (all producers be- } \\
\text { come shareholders }\end{array}$ & & $\begin{array}{l}\text { New Operations and Finance Directors } \\
\text { "appalled" at the "muddling" and the } \\
\text { "incompatible" operations across the } \\
\text { independent regions }\end{array}$ \\
\hline 2003 & $\begin{array}{l}\text { First "Enabler" Project } \\
\text { to establish standard } \\
\text { demand collection and } \\
\text { forecasting }\end{array}$ & $\begin{array}{l}\text { A system of linked XLSs } \\
\text { for this purpose is created }\end{array}$ & $\begin{array}{l}\text { Regions readily accept this standardiza- } \\
\text { tion and urge for operational use (e.g. } \\
\text { ordering) of the system }\end{array}$ \\
\hline
\end{tabular}




\begin{tabular}{|c|c|c|c|}
\hline Time & Business Developments & IT developments & Comments \\
\hline 2004 & $\begin{array}{l}\text { "Priority Analysis" pro- } \\
\text { ject starts; followed by } \\
\text { the "Involve" project to } \\
\text { determine a plan for } \\
\text { implementation of a } \\
\text { global standard transac- } \\
\text { tion process }\end{array}$ & & $\begin{array}{l}\text { This is seen as an essential precursor to } \\
\text { any global transaction process; two major } \\
\text { sub-projects area identified: classification } \\
\text { of transaction complexity; and: } \\
\text { Segmentation of customers by "value" } \\
\text { (to the CO-OP) }\end{array}$ \\
\hline 2005 & "MOP-B" is started & $\begin{array}{l}\text { The legacy central data } \\
\text { processing system is re- } \\
\text { placed by a skeleton ver- } \\
\text { sion of SAP (with SAP } \\
\text { and external consultants) }\end{array}$ & $\begin{array}{l}\text { This is the creation of an operational } \\
\text { model - "Modus Operandi - Baseline"; } \\
\text { SAP takes on role of central "Back- } \\
\text { office" }\end{array}$ \\
\hline 2006 & "MOP-P2" is started & $\begin{array}{l}\text { Adapting SAP to the } \\
\text { "Order-to-Cash" business } \\
\text { process created in the } \\
\text { process prototype }\end{array}$ & $\begin{array}{l}\text { "Prototype \& Pilot" in the US region - } \\
\text { highest business complexity and most } \\
\text { high-value customers }\end{array}$ \\
\hline 2007 & $\begin{array}{l}\text { "MOP-R" is started with } \\
\text { SAP, external consult- } \\
\text { ants and IBM help }\end{array}$ & $\begin{array}{l}\text { Centralized Customer } \\
\text { Service centre ("Middle } \\
\text { Office") }\end{array}$ & $\begin{array}{l}\text { This is the Roll-out of the SAP prototype } \\
\text { to all global regional and local offices; } \\
\text { In late } 2006 \text { commodity-customers and } \\
\text { low-volume customers are "switched" to } \\
\text { the central } 24 / 7 \text { service desk at CO-OP's } \\
\text { head office }\end{array}$ \\
\hline 2008 & $\begin{array}{l}\text { MOP-R continues; } \\
\text { a "once-over-lightly cus- } \\
\text { tomization" programme } \\
\text { is started }\end{array}$ & $\begin{array}{l}\text { On-line commodity trad- } \\
\text { ing is established with } \\
\text { spot and future contract } \\
\text { functionality }\end{array}$ & $\begin{array}{l}\text { Localization of the MOP-P2 prototype } \\
\text { proves difficult - the high-complexity } \\
\text { model is too difficult for smaller, simpler } \\
\text { offices }\end{array}$ \\
\hline $\begin{array}{l}2009 \\
\text { and } \\
\text { early } \\
2010\end{array}$ & MOP-R finishes & $\begin{array}{l}\text { Local modifications are } \\
\text { carried out where possi- } \\
\text { ble without affecting the } \\
\text { core of the global stan- } \\
\text { dards }\end{array}$ & $\begin{array}{l}\text { Most offices feel that they have lost some } \\
\text { of their prior operational efficiency be- } \\
\text { cause of an "unwieldy" SAP system; } \\
\text { A Post-Mortem and SAP-Next-Phase } \\
\text { Plan is muted for 2010/11 }\end{array}$ \\
\hline
\end{tabular}

This project is seen as the culmination and final implementation of a vision that was created started in 1992, when the then incoming CEO set out to bring about a change towards a centrally co-ordinated global enterprise. The first IIS project misinterpreted this intention and its failure was a significant set-back for the CO-OP - it significantly underscored the power and independence - of the regions. Corporatisation, however, once again put executive focus firmly on the need to standardise global transaction processes and systems. This time a global enterprise resource programme (ERP) was implemented, alas still with a significant residual of user dissatisfaction and unease.

\section{Conclusion (so far...)}

The data gathering phase of the research programme still has some distance to cover, but first observations are already beginning to crystallize the critical differences between the first and the second project:

- Business leads. The second project was entirely lead and driven by executive concerns about the integrity of the CO-OP's global business processes; this led to an analysis of the process structures that were in use. This in turn was then critically analysed in a study to establish the 
actual requirements of the business in each region/locality per se. A four-tier transaction architecture was developed as the end-product of this phase;

- IT follows. This extensive, zero-based business process analysis, design, calibration, and reconstruction work preceded all but small(est)-scale information systems acquisition projects ${ }^{5}$ work on the IS side by the best part of half a decade;

- Rational business analysis. As this process architecture work was done "by business people for business people" it effectively disarmed (irrational) turf politics and, as a matter of course, largely dismantled the negative aspects of the regional fiefdoms' operational autonomy;

- Relevant and appropriate expert assistance. In line with the acquisition-not-development strategy and policy consultancy and vendor assistance was utilised extensively (and intensively) for every phase/step/area of the project;

- Corporatisation. Changing the structure of the co-operative to a corporatized enterprise architecture enabled the introduction of opportunities for installing a world-class governance executive, far more commensurate with the CO-OP's size, importance in Australasia and overall global position; the culture of decision making and control that this move brought with it eventually permeated down the ranks and contrasts favourably, and exceedingly fruitfully, with the undisciplined parochialism often visible in the myopic strategic decisions that were made by the executive overseeing of the hapless previous project.

It is too early to attempt to put together how these first conceptualisations relate and form a comprehensive, overarching theoretical construct. However, first, conjectured, careful conceptualisations may be attempted.

It seems that the black-and-white contrast of Acceptance versus Rejection may well be too crude a model of user response. Redefining these discrete concepts as the extremes of a 'User Resistance' continuum could produce a better fit with the reality of the CO-OP's second project: users are still unhappy, but there is consent that the tangible effects of accepting integrated processes have brought significant results in terms of profitability, growth, and wealth of the CO-OP's shareholders. It therefore seems a tenable conclusion that the equilibrium reached after MOP-R is at the end of a cycle that has different attributes than the rejection cycle of the previous project. Figure 2 below depicts this first conjecture.

There is still much missing in this picture - the effects of CO-OP's specific flavour of corporatisation, the effects of increased global inter-activity as well as serious competition by experienced global operators, the impact of sea changes in the international use of information technology, to mention but a few areas that need to be exemplified, scrutinized, and understood in future data gathering. Also missing are detailed accounts of users' history and valuations. Reactions from customers ideally should conclude the data gathering. All this forms the research programme over at least the remainder of 2010 (but most likely well into 2011).

So far, however, all the indicators from this work-in-progress hold strong potential to elevate the grounded theory previously postulated significantly - in which way, though, it's still too early to guess.

\footnotetext{
${ }^{5}$ There was never a doubt that information systems would always be "acquired" - development, certainly of the inhouse variant, was from the outset not considered a feasible strategic options.
} 


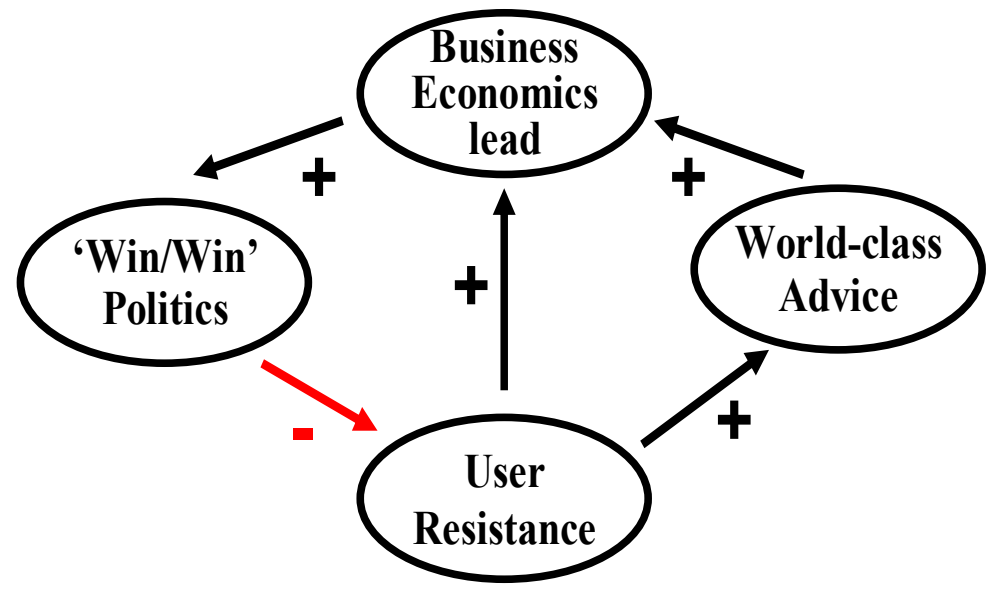

Figure 2. A (possible) Combined User Resistance Dynamic

\section{References}

Bateson, G. (1972). Steps to an ecology of mind: Collected essays in anthropology, psychiatry, evolution, and epistemology (pp. 68ff). San Francisco: Chandler Publishing.

British Computer Society. (2004). The challenges of complex IT projects. [Report to Members] London, UK: The Royal Academy of Engineering.

Buss, M. D. J. (1982). Managing international information systems. Harvard Business Review, Sep/Oct (60:5), 153-162.

Collins, R. W., \& Kirsch, L. (1999). Crossing boundaries: The deployment of global IT solutions (ch. 4,5). Practice-Driven Research in IT Management Series ${ }^{\mathrm{TM}}$. Cincinnati, OH.

Davenport, T. (1997). The bigger picture. CIO Magazine, 10(5), 88-96. Framingham, MA.

Davenport, T., \& Prusak, L. (1997). Information ecology: Mastering the information and knowledge environment. New York, NY: Oxford University Press.

Denzin, N. K., \& Lincoln, Y. S. (1994). Introduction. In N. K. Denzin \& Y. S. Lincoln (Eds.) Handbook of qualitative research (pp. 1-18). Thousand Oaks: Sage Publications.

Feyerabend, P. K. (1988). Against method (pp. 31ff). New York: Verso.

Flowers, S. (1996). Software failure: Management failure (ch. 3,4-8,9). New York, NY: John Wiley \& Sons.

Gallupe, R. B., \& Tan, F. B. (1999). A research manifesto for global information management. Journal of Global Information Management, 7(3), 5-18.

Glaser, B. G. (1978). Theoretical sensitivity (ch. 3,4-7). Mill Valley, CA: Sociology Press.

Glaser, B. G. (1992). Emergence vs. forcing: Basics of grounded theory analysis (ch. 1,2,5,8,11). Mill Valley, CA: Sociology Press.

Glaser, B. G. (1995). Grounded theory: A reader (Vols. I and II, ch. 3, 5, 7-14). Mill Valley, CA: Sociology Press.

Glaser, B. G. (1998). Doing grounded theory: Issues and discussions. Mill Valley, CA: Sociology Press.

Glaser, B. G., \& Strauss, A. L. (1967). The discovery of grounded theory (pp. 2-12). Hawthorne, New York: Aldine Publishing. 
Glaser, B. G., \& Strauss, A. L. (1994). Case histories and case studies. In B. G. Glaser (Ed.) More grounded theory methodology: A reader (pp. 233-245). Mill Valley, CA: Sociology Press. (Reprinted from B. G. Glaser \& A. L. Strauss. (1970). Anguish. Mill Valley, CA: Sociology Press.

Glass, R. L. (1998). Software runaways (ch. 3). Upper Saddler River, NJ: Prentice Hall PTR.

Guba, E. G., \& Lincoln, Y. S. (1994). Competing paradigms in qualitative research. In In N. K. Denzin \& Y. S. Lincoln (Eds.) Handbook of qualitative research (pp. 105-117). Thousand Oaks: Sage Publications.

Hamelink, C.J. (1984). Transnational data flows in the information age (ch. 4). Lund, Sweden: StudentLitteratur AB.

Herrscher, E. G., \& Herrscher, R. M. (1990). Systemic aspects of hyperinflation in Argentina. Human Systems Management, 9(2), 89-105.

Keen, P. G. W., Bronsema, G. S., \& Auboff, S. (1982). Implementing common systems: One organisation's experience. Systems, Objectives and Solutions, 2, 125-142.

Lehmann, H. P. (1996). Towards a common architecture paradigm for the global application of information systems. In B. C. Glasson, D. R. Vogel, P. W. Bots, \& J. F. Nunamaker (Eds.), Information Systems and technology in the international office of the future (pp. 199-218). London: Chapman and Hall.

Lehmann, H. P. (1997). A definition of research focus for international information systems. Proceedings of the Thirtieth Annual Hawaii International Conference on Systems Sciences, Maui, Hawaii.

Lehmann, H. P. (1998). The design of information systems for the international firm: What are the critical issues? S. J. Gray \& S. Nichols (Eds), Proceedings of the Inaugural Conference of the Australia-New Zealand International Business Academy. Melbourne, November 1998.

Lehmann, H. P. (2000). The fatal politics of multinational information systems: A case study. Journal of Information Technology Cases \& Applications, 2(3), 40-64.

Lehmann, H. P. (2003). An object oriented architecture model for international information systems? An exploratory study. Journal of Global Information Management, Vol.11 (3), p1-18; London.

Lehmann, H. P. (2004). The Australasian Produce Co-Operative: A global information systems project. Communications of the AIS (CAIS), 13(March), Article 17. [This case submission also includes The APCO Case - Instructor Materials, comprising MS PowerPoint presentation (31 Slides) of the case history and analysis; and a Case Teaching Note; both formatted as web-downloadable documents.]

Lehmann, H. P. (2005) A focusing framework for international information system architectures - The case for object-orientation. In M. G. Hunter \& F. B. Tan (Eds.), Advanced Topics in Global Information Management (Vol. 4, Ch.1, pp.1-21) Harrisburg, PA; IGI Global.

Lehmann, H. P. (2010). The dynamics of international information systems - Anatomy of a grounded theory investigation. Springer, New York. [Also as an E-Book on SpringerLink at http://www.springerlink.com/content/k55007/]

Lehmann, H. P., \& Gallupe, R. B. (2005). Information systems for multinational enterprises - Some factors at work in their design and implementation. Journal of International Management, 11(4), 28-49.

Lehmann H. P., Urquhart. C., \& Myers, M. (2004). Putting the theory back into grounded theory: A framework for grounded theory studies in information systems. University of Auckland Working Paper.

Lewin, K. (1938). The conceptual representation and the measurement of psychological forces. (Vol. I, No. 4 of the series Contributions to Psychological Theory, ch. 5,7-9). Durham, North Carolina: Duke University Press.

Lewin, K. (1952). Field theory in social science: Selected theoretical papers (ch. 5,8). (D. Cartwright, Ed.) London, United Kingdom: Tavistock.

Lindsley, D. H., Brass, D. J., \& Thomas, J. B. (1995). Efficacy-performance spirals: A multilevel perspective. Academy of Management Review, 20(3), 645-678. 
Martin, P. Y., \& Turner, B. A. (1986). Grounded theory and organizational research. The Journal of Applied Behavioral Science, 22(2), 141-157.

Maruyama, M. (1968). The second cybernetics: Deviation-amplifying mutual causal processes. In W. Buckley (Ed.), Modern systems research for the behavioral scientist: A sourcebook (pp. 297-313). Chicago: Aldine.

Miles, M. B., \& Huberman, A. M. (1994). Qualitative data analysis: An expanded sourcebook (2nd ed., ch. 1,3-5,7). Thousand Oaks: Sage Publications.

Montazemi, A. R., \& Chan, L. (1990). An analysis of the structure of expert knowledge. European Journal of Operational Research, 45(2-3), 275-292.

Orlikowski, W. J. (1993). CASE tools as organisational change: Investigating incremental and radical changes in systems development. MIS Quarterly, Sept, 309-337.

Pettigrew, A. M. (1990). Longitudinal field research on change: Theory and practice. Organization Science, 1(3), 267-292.

Sethi, V., \& Olson, J. E. (1993). An integrating framework for information technology issues in a transnational environment. In S. Palvia, P. Palvia, \& R. Zigli (Eds.) Global issues in information technology (pp. 227-253). Harrisburg, PA: Idea Publishers.

Strauss, A. L. (1987). Qualitative analysis for social scientists (ch. 2-5). Cambridge University Press.

Strauss, A., \& Corbin, J. (1990). Basics of qualitative research. - Grounded theory procedures and techniques (ch. 2-9). London: Sage Publications.

Strauss, A., \& Corbin, J. (1994). Grounded theory methodology: An overview. In N. K. Denzin \& Y. S. Lincoln (Eds.) Handbook of qualitative research (pp. 273-285). Thousand Oaks: Sage Publications.

Urquhart, C., Lehmann, H. P., Myers, M. D. (2010). Putting the "Theory" back into Grounded Theory: A Framework for Grounded Theory Studies in Information Systems; Information Systems Journal, Volume 20 Issue 4; pp. 357-381

Weick, K. E. (1979). The social psychology of organizing (ch. 3-5). Reading, MA: Addison Wesley.

Yin, R. K. (1989). Case study research: Design and methods (ch. 2-9). Newbury Park, CA: Sage Publications.

Yourdon, E. (1997). Death march: The complete software developer's guide to surviving mission impossible projects (ch. 5). Upper Saddler River, NJ: Prentice Hall PTR.

\section{Biography}

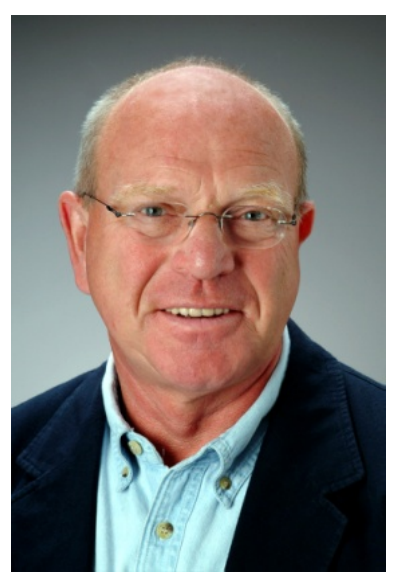

Hans Lehmann, Austrian by birth, is a management professional with some 25 years of business experience with information technology. After a career in data processing line management in Austria and South Africa he worked for some twelve years with Deloitte's, an international management consultancy firm. Hans' work experience spans continental Europe, Africa, the United Kingdom, North America and Australasia, specialising in managing of implementation of information systems for multi-national companies. In 1991 Hans joined the University of Auckland, New Zealand, researching the strategic management of global information technology. In 2003 he moved to Victoria University, where his current research aims at the application of wireless and mobile business technology. Hans has spoken at numerous international conferences and has well over 100 refereed publications to his name. 